\title{
MATERIAŁY
}

Joanna Jarzębak-Kolodziejczyk

BHW 39/2018

Wydziat Humanistyczny

ISSN 1233-2224

Uniwersytet Pedagogiczny im. KEN w Krakowie

DOI: $10.14746 /$ bhw.2010.39.7

ORCID: 0000-0001-8392-7925

\section{Podróże edukacyjne synów szlacheckich w świetle korespondencji Jakuba Dunina z wojaży po Europie w latach 1699-1703}

\begin{abstract}
Educational journeys of noble sons in the light of Jakub Dunin's correspondence from the travel around Europe in 1699-1703

The article aims to show the issue of educational travels of noble youth in the modern era. The source is the correspondence of Jakub Dunin from his journeys around Europe in 1699-1703, addressed to father Franciszek Świętosław. The mentioned letters (stored in the National Archives in Krakow in the Tomkowicz Archive from Kobiernice) provide important information referring to the reasons for travelling, travel expenses and the companions.

Particularly noteworthy are colorful descriptions of the social life lived in European manors. For example, the author visited Versailles of Louis XIV and provided a detailed description of various ceremonies and court entertainment. Foreign journeys posed an opportunity to learn about foreign cultures, political systems or armies. This encouraged nobility sons' reflections which they shared with relatives back in Poland. As a result, the travel correspondence abounds in individual interpretations, for example, of the then political developments on the international arena. When confronted with facts, they add extra value to the publication.
\end{abstract}

Keywords: journey, correspondence, education, traditions, place

Źródła o charakterze epistolarnym stanowią nieoceniony materiał poznawczy dla badaczy zjawisk kulturowo-społecznych zarówno w kwestii zachodzących relacji interpersonalnych, jak i w odniesieniu do konkretnych zdarzeń natury obyczajowej ${ }^{1}$. Niewątpliwie do faktów tego typu należą wszelkiego rodzaju podróże, które na przestrzeni

1 Zob. K. Maliszewski, Komunikacja społeczna w kulturze staropolskiej. Studia z dziejów kształtowania się form i treści społecznego przekazu w Rzeczypospolitej szlacheckiej, Toruń 2001; Epistolografia w dawnej Rzeczypospolitej, t. VI (stulecia XVI-XIX). Nowa perspektywa historyczna i językowa, red. P. Borek, M. Olma, Kraków 2015; Kobiece kręgi korespondencyjne w XVII-XIX wieku, red. B. Popiołek, U. Kicińska, A. Słaby, 
stuleci pozostawiły ślady w postaci diariuszy, instrukcji podróżniczych, spisów nakładów finansowych, i co najważniejsze, szeregu listów będących nośnikiem ważkich informacji².

Ludzie epoki staropolskiej, zwłaszcza spośród środowisk najwyżej usytuowanych, doceniali rolę edukacji jako nieodzownego elementu funkcjonowania we właściwej sobie warstwie społecznej. Elementarne wykształcenie zdobywano najczęściej w rodzinnym domu przy pomocy specjalnie zatrudnianych guwernerów (nierzadko cudzoziemców). Popularną formą edukacji było także uczęszczanie do szkół prowadzonych przez zakony jezuitów lub pijarów ${ }^{3}$. Niezbędnym elementem oświaty młodego człowieka było również przebywanie na dworze królewskim, bądź częściej w kręgach magnackich, gdzie nabywano odpowiedniej ogłady oraz umiejętności przydatnych w sferze towarzyskiej. Ponadto szkolono się tam w służbie dyplomatycznej i poznawano arkana ówczesnej polityki ${ }^{4}$.

Istotnym wariantem dydaktycznym dla młodzieży staropolskiej były zagraniczne podróże. Motywy podejmowania tych przedsięwzięć jawią się bardzo wielostronnie, ponieważ stanowią powiązanie kilku ważnych elementów, mianowicie: edukacji szkolnej, samokształcenia i umiejętności praktycznych nabywanych w ich trakcie ${ }^{5}$. Szlachta nie zawsze była ukontentowana z poziomu i toku kształcenia oferowanego w Rzeczypospolitej, dlatego wysyłała swoich synów za granicę, aby zdobywali wiedzę na sławnych europejskich wszechnicach ${ }^{6}$. Poza nauką sensu stricto młodzież miała również poznawać nowe środowiska, obyczaje, relacje społeczno-polityczne, doskonalić sztukę władania

Warszawa 2016; Źródła do dziejów staropolskich podróży edukacyjnych, red. D. Żołądź-Strzelczyk, M. E. Kowalczyk, Wrocław 2017.

${ }^{2}$ Zob. B. Popiołek, Na marginesie ważnych spraw. Listy kobiet epoki saskiej, w: Rola i miejsce kobiet w edukacji i kulturze polskiej, t. 1, red. W. Jamrożek, D. Żołądź-Strzelczyk, Poznań 1998, s. 89-108; B. Rok, Opis podróży Wacława Sierakowskiego (1741-1806) po Europie w latach 1763-1769, w: Z badań nad Rzeczypospolita w czasach nowożytnych, red. K. Matwijowski, Wrocław 2001, s. 131-148; R. Dzięgielewski, Przygotowanie młodzieży do podróży akademickiej w XVI-XVIII wieku na przykładzie traktatów apodemicznych, w szczególności „Brewiarza apodemicznego” gdańszczanina Samuela Zwickera, Gdańsk 2015, s. 235-242; A. Penkała, „Nowiny śle pewne i dobre”. Szlacheckie podróże w świetle wybranej matżeńskiej korespondencji XVII i XVIII wieku, w: Via viatores quaerit. Mobilność społeczna w dziejach krajów Grupy Wyszehradzkiej, red. A. Teterycz-Puzio, L. Kościelak, E. Łączyńska, Słupsk 2016, s. 167-176; D. Żołądź-Strzelczyk, ,, Refleksje synowi wyjeżdżajacemu do Widnia" - Feliksa Czackiego wskazówki dla syna, w: Staropolskie podróżowanie, red. B. Rok, F. Wolański, Kraków 2016, s. 271-280.

${ }^{3}$ Szkolnictwo organizowane przez zakony na ogół skupiało się na kształceniu na poziomie średnim. Uczono np. gramatyki, poetyki, retoryki, dodatkowo filozofii bądź teologii. Ponadto dbano o rozwój duchowo-moralny wychowanków. Od czasów kasaty zakonu jezuitów, dokonanej przez papieża Klemensa XIV w lipcu 1773 r. oraz powstania Komisji Edukacji Narodowej (14 października 1773 r.) dawne kolegia zakonne przeszły pod zarząd państwowy, co pozwoliło na ich gruntowną reorganizację (K. Puchowski, Europejski rodowód kolegiów szlacheckich w Rzeczypospolitej. Rekonesans, w: Staropolski ogląd świata - problem inności, red. F. Wolański, Toruń 2007, s. 183-200).

${ }^{4}$ D. Żołądź-Strzelczyk, Wychowanie dziecka w świetle staropolskiej teorii pedagogicznej, w: Od narodzin do wieku dojrzałego: dzieci i młodzież w Polsce. Częśś 1, Od średniowiecza do wieku XVIII, red. M. Dąbrowska, A. Klonder, Warszawa 2002, s. 101-104.

${ }^{5}$ D. Żołądź-Strzelczyk, Podróże edukacyjne w staropolskiej myśli pedagogicznej, „Chowanna”, t. 2, 1998, s. 32.

${ }^{6}$ Przestrogi i nauki dla dzieci: instrukcje rodzicielskie (XVIII w.), red. M. E. Kowalczyk, D. Żołądź-Strzelczyk, Wrocław 2017. 
językami obcymi oraz, co najistotniejsze od strony indywidualnej, poznawać nowych ludzi, nawiązywać kontakty i przyjaźnie?

Idea podróży edukacyjnych znana była już w średniowieczu, a upowszechniła się właśnie w dobie nowożytnej, co wiązało się z renesansowym pojęciem wszechstronnego wykształcenia i ciekawości świata. Zagraniczne wojaże nie straciły na znaczeniu wraz z upływem czasu, zmieniła się tylko ich koncepcja oraz kierunki peregrynacji. Najczęściej odwiedzano państwa Europy Zachodniej, w głównej mierze kraje włoskie, niemieckie, Francję, Niderlandy i rzadziej Anglię ${ }^{8}$ Ogólnie rzecz ujmując, w epoce staropolskiej funkcjonowały dwa najistotniejsze typy wojaży. Pierwszy to tzw. peregrinatio academi$c a$, czyli podróże naukowe podejmowane w celu kształcenia się w konkretnych europejskich placówkach oświatowych ${ }^{9}$. Drugi, bardziej znany, można określić mianem Grand Tour, ponieważ w zamyśle organizowano go tak, aby nie zważając na długość trwania eskapady, odwiedzić jak największą liczbę miejsc oraz poznać zagraniczne społeczeństwa z wielowymiarowej perspektywy ${ }^{10}$.

Wiek XVIII uznawany jest za pierwsze stulecie wielkiej turystyki, także z tego względu, iż zmienia się wówczas specyfika podróżowania. Mobilność społeczna staje się zjawiskiem powszechnym. Co więcej, przepływ informacji uwarunkowany jest sprawnym funkcjonowaniem poczty ${ }^{11}$. Przedłużająca się nieobecność w domu rodzinnym powodowała, że synowie szlacheccy przebywający za granicą starali się przesyłać regularne wieści ze swojej wyprawy oraz oczekiwali wiadomości z życia najbliższych im osób. W tego typu korespondencji poruszano wiele kwestii natury prywatnej, społeczno-kulturowej, politycznej i ekonomicznej, co tworzy niezwykle ciekawy ogląd ówczesnych realiów ${ }^{12}$.

Zachowana w Archiwum Narodowym w Krakowie (Oddział I) korespondencja rodziny Duninów ${ }^{13}$ doskonale wpisuje się w nurt staropolskiej epistolografii. Spośród setek

${ }^{7}$ D. Żołądź, Ideały edukacyjne doby staropolskiej. Stanowe modele i potrzeby edukacyjne szesnastego i siedemnastego wieku, Warszawa-Poznań 1990, s. 65.

${ }^{8}$ M. Kamecka, „Do cudzych krajów”. Edukacyjne podróże szlachty polskiej do Francji w epoce saskiej, Białystok 2012, s. 33-36.

${ }^{9}$ U. Kicińska, Pedagogiczny aspekt podróżowania $w$ dawnej Polsce, w: Polski Grand Tour w XVIII i początkach XIX wieku, red. A. Roćko, Warszawa 2014, s. 33-34.

10 A. Mączak, Peregrynacje. Wojaże. Turystyka, Warszawa 1984, s. 126.

$11 \mathrm{~W}$ epoce nowożytnej istniała dobrze rozwinięta sieć połączeń pocztowych na skalę europejską. Rzeczpospolita nie była w tej kwestii wyjątkiem. Już w XVI w. stworzono zagraniczne szlaki (np. na trasie Kraków - Wenecja), natomiast u schyłku XVII i w 1 poł. XVIII stulecia ukształtowało się kilka najistotniejszych centrów pocztowych, mianowicie: Kraków, Warszawa, Gdańsk, Toruń, Lublin czy Lwów, do których napływały przesyłki z kraju i z zagranicy. System ów gwarantował regularny przepływ informacji w formie gazet rękopiśmiennych, druków ulotnych, staropolskich periodyków, a co najważniejsze pozwalał na ekspedycję wszelkiego rodzaju korespondencji (K. Maliszewski, op. cit., s. 31-34).

12 B. Popiołek, Peregrynacje edukacyjne i poznawcze w źródłach czasów saskich, w: Polski Grand Tour w XVIII i poczatkach XIX wieku, red. A. Roćko, Warszawa 2014, s. 51-55.

${ }^{13}$ Niniejsza publikacja dotyczy przedstawicieli skrzyńskiej linii Duninów herbu Łabędź, uznającej za swą rodową siedzibę Wielkie Skrzynno (zwane też Skrzynno), znajdujące się w ziemi radomskiej (D. Kupisz, Rody szlacheckie ziemi radomskiej, Radom 2009, s. 57-70). 
listów, podejmujących sprawy istotne nie tylko dla samej familii, ale również dla Rzeczypospolitej, na uwagę zasługują relacje z podróży po Europie w latach 1699-1703, pisane przez Jakuba Dunina (zm. 1730) ${ }^{14}$ do ojca Świętosława Franciszka (zm. 1706) ${ }^{15}$.

Swą peregrynację rozpoczyna Dunin wiosną 1699 r. ${ }^{16}$ Należy podkreślić, że podróż ta nie jest wynikiem samodzielnej inicjatywy, lecz protekcji jakiej udzielili mu Radziwiłłowie, Jakub bowiem wyrusza w charakterze towarzysza książąt: Jana Mikołaja (16811729) i Michała Antoniego (1687-1721) ${ }^{17}$, sam mając zapewne nie więcej niż 18 lat. Zaistniała sytuacja nie jest zaskakująca, ponieważ często zdarzało się, iż wraz z młodymi magnatami na zagraniczne wojaże udawali się protegowani pochodzący z mniej zamożnych domów. Warto dodać, że młodzież szlachecka zazwyczaj była związana zależnościami klientalnymi z rodziną swych protektorów ${ }^{18}$. Potwierdza to przykład Jakuba Dunina, który wielokrotnie wyraża swą wdzięczność książętom za możliwość odbycia edukacji za granicą pod ich kuratelą wspominając iż mnie z łaski Bożej [...] laska Księstwa Ich MCiów Dobrodziejstwa nie odmieniła się której uznawam dokumenta ${ }^{19}$.

Pierwotnym celem podróży było dotarcie do Berlina, dokąd młodzież eskortował bliżej nieznany pan Sakowicz. Jakub wspomina, iż obecnie stara się ekspediować jak największą ilość listów, ponieważ potem trudniejsza będzie i z niemałym kosztem korespondencja $^{20}$. Ponadto nadmienia, że listy do rodziny będzie wysyłał razem z pismami Radziwiłłów na pocztę do Warszawy, co jest rzeczą naturalną, ponieważ przesyłki z krajów niemieckich kursowały w czasach saskich na stałej trasie prowadzącej właśnie do stolicy Rzeczypospolitej. Dunin zdaje sobie sprawę z faktu, iż czeka go długa, może nawet kilkuletnia rozłąka $\mathrm{z}$ domem i przygotowuje na to także ojca, pisząc: $N a$ tym $n a$ dtuga zanosi się peregrynację bo Księstwo Ich Mość chca być w Hiszpanii, Portugalii,

\footnotetext{
${ }^{14}$ Jakub Dunin ze Skrzynna - starosta radomski, regent kancelarii koronnej i referendarz wielki koronny (w okresie peregrynacji nie piastował jeszcze żadnej z podanych funkcji publicznych); zob. W. Konopczyński, Jakub Dunin ze Skrzynna, w: Polski Słownik Biograficzny, t. V, Kraków 1939-1946, s. 474-475.

15 Świętosław Franciszek Dunin ze Skrzynna - chorąży parnawski, regent i sędzia grodzki radomski, wojski i stolnik sandomierski. Ze związku z Zofią z Manowskich miał trzech synów: Jakuba, Piotra (zm. 1737) i Jana (zm. 1733).

${ }^{16}$ Archiwum Narodowe w Krakowie Oddział I (dalej ANKr Oddział I), Archiwum Tomkowiczów z Kobiernic (dalej ATKob) 33, k. 1-7, Listy Jakuba Dunina do Świętosława Franciszka Dunina, Radom i Opoczno, 1699.

${ }_{17}$ Synowie ks. Dominika Mikołaja Radziwiłła (1653-1697), kanclerza litewskiego oraz Anny Marianny Połubińskiej. Jan Mikołaj po śmierci ojca został ordynatem kleckim, pełnił także urząd krajczego Wielkiego Księstwa Litewskiego (od 1699 r.) oraz w późniejszym czasie wojewody nowogrodzkiego (od 1709 r.). Michał Antoni był starostą lidzkim, przyszłym założycielem szydłowieckiej linii Radziwiłłów oraz krajczym litewskim od 1706 r. (S. Górzyński, J. Grala, W. Piwkowski, V. Urbaniak, T. Zielińska, Radziwiłłowie herbu Trąby, Warszawa 1996, s. 26-31).

${ }_{18}$ M. Chachaj, Orszak magnata odbywającego podróż edukacyjną (wiek XVI-XVIII), w: Patron $i$ dwór. Magnateria Rzeczypospolitej w XVI-XVIII wieku, red. E. Dubas-Urwanowicz, J. Urwanowicz, Warszawa 2006, s. 177.

19 ANKr Oddział I, ATKob 33, k. 9, List J. Dunina do Ś. F. Dunina, b. m. 2 XI 1699.

${ }^{20}$ Ibidem, k. 10.
} 
Wenecji i innych Państwach odlegtych ${ }^{21}$. Zatem wspomniana podróż wpisywała się w zasadę XVIII-wiecznej Grand Tour z niebagatelnym pożytkiem dla peregrynantów mających poznać kraje zachodniej Europy bez względu na czas i koszty jej realizacji.

Program podróży uwzględniał także naukę szkolną na co wskazuje list datowany na 19 marca 1700 r. z Paryża, w którym Jakub Dunin relacjonuje ojcu, że wraz z książętami Radziwiłłami przebywa w kolegium ojców jezuitów z czegom wielce kontent gdyż prędszy $i$ większy za łaska Boża mieć moge nad innych profit $w$ języku francuskim [...] od konwersacji z Ich MCiami P.P. Polakami których [...] przybywa [... $]^{22}$. Szkoły jezuickie we Francji uchodziły za jednostki niezwykle elitarne, a najistotniejszymi spośród nich były: Collège de la Flèche w Anjou oraz Collège de Louis-le-Grand w Paryżu. Jakub Dunin znajduje się w drugiej ze wspomnianych placówek, założonej w 1584 r. jako Collège de Clermont, natomiast ówcześnie znanej pod zmienioną nazwą, mającą podkreślić charakter roztaczanej nad nią królewskiej kurateli ${ }^{23}$. Peregrynant wspomina o wielu znacznych osobistościach mających pojawić się w murach wszechnicy, bądź już tam przebywających, np. o księciu Sanguszce (prawdopodobnie Pawle Karolu) ${ }^{24}$. Co więcej, dodaje, iż w tym kolegium jest samych Książat Francuskich i cudzoziemskich piętnaście, innych przeszło tysiąc stołowników z którymi do stołu siadać będziemy [... $]^{25}$. Potwierdzeniem wzmiankowanych poprzednio relacji klientalnych jest prośba i dyskretne upomnienie wystosowane do Świętosława Franciszka, aby wysyłał regularną korespondencję do protektora swego syna, gdyż zobowiązał się do tego już wcześniej, natomiast [...] Ksiażęta Ich Mość Dobrodziejstwo a osobliwie Ksiązę Jego Mość Krajczy WXL [Jan Mikołaj Radziwiłł] mile wspominajac WMD $i$ [między pierwszego] z przyjaciół swoich licząc ma za znak nie afektu i niekonfidencji WMD że z nim przynajmniej co miesiac nie korespondujesz racz tedy WMD odezwać się do niego ${ }^{26}$.

Dunin jest osobą niezwykle ambitną i w pełni docenia możliwości jakie, dostarcza mu zagraniczna peregrynacja. Jednakże wydatki związane z edukacją są na tyle duże, że zmuszony jest nieustannie zabiegać u ojca o fundusze materialne, aby pokryć koszty utrzymania i opłacenia prywatnych nauczycieli, a przy tym nie musieć zadłużać się u lichwiarzy. Przykład takiej prośby jest następujący: To mnie ciężko [dotyka], że [...] nie mam żadnej rezolucji [decyzji] na najniższa prośbę moja, która w przeszlych listach [przedstawiałem] WMD [...] a w Paryżu lubo chętnie na borg dadza, ale potem sowicie i ledwie nie dwojako płacić potrzeba [...] dlatego i Ja nie uspokoiłem Magistrów swoich.

\footnotetext{
21 Ibidem.

22 ANKr Oddział I, ATKob 33, k. 13-14, List J. Dunina do Ś. F. Dunina, Paryż 19 III 1700.

${ }^{23}$ K. Puchowski, op. cit., s. 188-189.

${ }^{24}$ ANKr Oddział I, ATKob 33, k. 14, List J. Dunina do Ś. F. Dunina, Paryż 19 III 1700.

25 Ibidem.

${ }^{26}$ ANKr Oddział I, ATKob 33, k. 33, List J. Dunina do Ś. F. Dunina, Paryż 14 VI 1701.
} 
Drugim zaś, którzy sa trzeba będzie zapłacić [...]. Czekam tylko dobroczynnej taski $W M D$ o którą [...] przykrzyć [się] najniższymi prośbami muszę $e^{27}$.

Istotnym dla niego jest fakt, iż jako książęcy towarzysz może mieszkać w wynajmowanym przez Radziwiłłów pałacu, co więcej otrzymuje od nich roczną pensję $e^{28}$, umożliwiającą na częściowe pokrycie ekspens. Jakub stara się na bieżąco informować rodzica o swoich dokonaniach, mianowicie wspomina o ćwiczeniach z języka francuskiego, w którym poczynił znaczne postępy. Wymienia również: fechtowanie na szpady, fortyfikację, granie na instrumencie taniec [...] także bardzo potrzebny [...] mnie, który zawsze bywam z Książęciem na róznych aktach. Inne do wojny należace [ćwiczenia] we Włoszech będę perfekcjonować ${ }^{29}$. Zakres kształcenia jawi się zatem jako wieloaspektowy. Nie skupiano się jedynie na przyswajaniu wiedzy, lecz dbano także o nabywanie określonych umiejętności, niezbędnych dla młodego szlachcica. Doskonalono chociażby sztukę szermierki czy predyspozycje przydatne w życiu towarzyskim. Ponadto każdy z peregrynantów miał okazję spotkać wiele znacznych osobistości, nie tylko cudzoziemców, lecz co ważniejsze rodaków również pobierających nauki za granicą. Jakub jest zadowolony z zawartych korzystnych znajomości, o czym pisze następująco: jednak największy mam profit że $z$ wielu godnych i magnorum nominum [wielkiego nazwiska] z Polski ludzi [...] zabratem konfidencje i wszyscy na mnie taskawi. Owo zgoła wszystko mi idzie wedtug myśli szczególnie tylko pomyślnej $[\ldots]^{30}$.

Niezwykle doniosłym wydarzeniem, wzbudzającym wielkie emocje u Jakuba Dunina jest wizyta w Wersalu, szczegółowo przedstawiona w liście datowanym 21 maja $1700 \mathrm{r}$. z Paryża. Poniższy fragment korespondencji ukazuje wycinek z barwnego życia toczącego się na królewskim dworze, gdzie gości podejmuje się z największymi honorami, bowiem: [...] rozkazal król JMC Francuski [Ludwik XIV] na ten czas [...] by wody graty $z$ których in diversas species [z różnych materiałów] porobione cum incrdibili sumptu [niesamowitym kosztem] fontanny różne z podziwieniem wyrażały figury [...] czego wypisać niepodobna [...]. Dąb [...] zrobiony stojący w ogrodzie z którego każdego listka woda strumieniami bez przestanku ciekta. Po widzeniu i graniu tych wód (co wzięto z godzin pięć lubośmy w rulach [powozach] królewskich jeździli po ogrodzie). Pojechaliśmy w Batach [łodziach] królewskich do drugiego Pałacu w tymże ogrodzie będacego kanatem, więc że Księstwo Ich Mości mieli z soba [...] Damy w kompanii kazali dać dla nich kolację cukrowa na batach, na której było wielu tak Francuskich jako i cudzoziemskich kawalerów którzy dla widzenia wód grających asystowali Księstwu IchMościom $[\ldots]^{31}$.

\footnotetext{
${ }^{27}$ ANKr Oddział I, ATKob 33, k. 23-24, List J. Dunina do Ś. F. Dunina, Paryż 6 VIII 1700.

${ }^{28}$ ANKr Oddział I, ATKob 33, k. 15, List J. Dunina do Ś. F. Dunina, Paryż 19 III 1700.

${ }^{29}$ ANKr Oddział I, ATKob 33, k. 32, List J. Dunina do Ś. F. Dunina, Paryż 22 V 1701.

${ }^{30}$ Ibidem.

${ }^{31}$ ANKr Oddział I, ATKob 33, k. 17-18, List J. Dunina do Ś. F. Dunina, Paryż 21 V 1700.
} 
Ludwik XIV starał się oczarować zagranicznych przybyszy swą podparyską siedzibą. Książęta Radziwiłłowie (a wraz z nimi Jakub Dunin) są tam przyjmowani w charakterze gości, specjalnie bowiem dla nich przewidziano różnorodne rozrywki. Pierwsza z nich obejmowała przejażdżkę po wersalskich ogrodach połączoną z podziwianiem kunsztownie wykonanych fontann, które nazywano „grającymi wodami”, ponieważ towarzyszył im akompaniament muzyczny. Następnie młodzież płynęła na specjalnych łodziach (batach) do samego pałacu, umilając sobie czas spożywaniem słodkiej kolacji. Pobyt w Wersalu wywarł na Jakubie ogromne wrażenie, co nie jest faktem zaskakującym, ponieważ była to pierwsza okazja, kiedy mógł on zetknąć się z życiem na jednym z najświetniejszych dworów europejskich. Z pewnością potraktował tę wizytę jako wielkie wyróżnienie.

Kolejny punkt paryskiej eskapady znalazł również odzwierciedlenie we wspomnianym liście do ojca. Jakub Dunin relacjonuje: Drugi dzień (...) zabrat mi objazd do Miasteczka Świętego Dionizego ${ }^{32}$ na anniwersarz króla Nieboszczyka Francuskiego [Ludwika XIII] [...], gdzie zwyczajne widzieliśmy ceremonie. Potem ogląaliśmy różnych królów Francuskich mauzola z alabastru wyrobione, ale te nec umbra [nie są porównywalne] do tych [statui] alabastrowych, których peten ogród wersalski. Skarbiec zaś peten drogich kamieni, złota i różnych świętych wielkich relikwii. Powróciwszy do Paryża sprawit koncert Ksiażę JM Krajczy [Jan Mikołaj Radziwiłł] w niedzielę na który przedniejsi Magistrowie muzyki grali na instrumentach swoich, gdzie było Książat z pięć między innymi Ksiaże [...] Gotha koligat króla JMCi Polskiego [Augusta II Wettyna], także Dam godnych wiele i Postów cudzoziemskich [...] petne lubo dość przestronne apartamenta. Po skończonym koncercie noszono piramidy cukrowe i likwory różne [wspaniałe] ${ }^{33}$.

Podróżom edukacyjnym towarzyszył również kontekst turystyczno-poznawczy, co potwierdza przytoczony opis, w którym młodzież przebywa w mauzoleum królów francuskich w Opactwie St. Denis, nie tylko uczestnicząc w nabożeństwie sprawowanym w rocznicę śmierci króla Ludwika XIII, lecz także zwiedzając wnętrze świątyni. Wrażenie, jakie wywarła na Duninie odwiedzona wcześniej rezydencja w Wersalu nie ustępuje po obejrzeniu tego mistycznego i jakże istotnego dla historii Francji miejsca. Nawet alabastrowe rzeźby, relikwie i drogocenne klejnoty są w stanie wzbudzić w autorze większych odczuć niż wersalski zespół pałacowo-parkowy.

Peregrynanci przebywający w Paryżu otaczali się kręgiem najznamienitszych osobistości nie tylko pochodzących z domów magnackich Rzeczypospolitej, lecz także person należących do cudzoziemskiej elity. Radziwiłłowie nie szczędzili środków na odpowiednie promowanie swej familii za granicą, czemu miały służyć chociażby organizowane przez nich koncerty oraz wydawane przyjęcia na które zapraszali książąt krwi, damy z wyższych sfer oraz ambasadorów. Jakub Dunin miał doskonałą sposobność, aby nawią-

\footnotetext{
${ }^{32}$ Mowa o Opactwie św. Dionizego (St. Denis), postrzeganego za pierwszego biskupa Paryża. Od VI w. uznawane było za oficjalną nekropolię francuskich monarchów.

33 ANKr Oddział I, ATKob 33, k. 19-20, List J. Dunina do Ś. F. Dunina, Paryż 21 V 1700.
} 
zać wówczas znajomości, które mogły okazać się korzystne dla jego przyszłej kariery. Ponadto uczył się sztuki konwersacji, nabierał manier i ogłady w życiu salonowym. Co ważniejsze jednak, kierował swoją ciekawość ku sferze obyczajów, dyplomacji i stosunków międzynarodowych, jakie panowały w ówczesnej Europie.

Kwestie polityczne znajdują odzwierciedlenie w korespondencji Dunina datowanej na 2 września 1700 r. oraz 22 maja, 14 czerwca i 29 sierpnia 1701 r. Jakub w znacznej mierze czerpie informacje $\mathrm{z}$ gazet francuskich oraz angielskich, ponadto wykorzystuje możliwości jakie daje mu obecność na królewskim dworze. Wszystkie zaobserwowane tam zdarzenia, opisuje w listach do ojca, np. relacjonuje konflikt pomiędzy Ludwikiem XIV a kardynałem de Bouillon ${ }^{34}$, który wobec nieposłuszeństwa duchownego spowodował konfiskatę jego majątku, jednak królowa Jej Mość Polska ${ }^{35}$ i niektórzy [książęta] pensjami swymi w Rzymie utrzymuja na afront królowi ${ }^{36}$.

Poza dworskimi intrygami Jakub Dunin jest bardziej zainteresowany sytuacją rozgrywająca się na europejskiej scenie politycznej. Warto zaznaczyć, iż w czasie jego pobytu w Paryżu toczone są paralelnie dwa istotne konflikty militarne, które w decydujący sposób wpłynęły na układ sił politycznych na kontynencie, mianowicie III wojna północna (1700-1721) oraz wojna o sukcesję hiszpańską (1701-1714). Pierwsza z nich prowadzona jest pomiędzy państwami tzw. Ligii Północnej (głównie Rosją, Danią, Saksonią) a Szwecją, Hetmanatem i Turcją. Rzeczpospolita również zostaje zaangażowana w ów antagonizm ze względu na łączącą ją z Saksonią unię personalną, toteż wydarzenia z nim związane nie mogą ujść uwadze Dunina. Natomiast drugi z konfliktów rozgrywa się pomiędzy jednymi z największych mocarstw europejskich, czyli Francją (wspieraną przez Hiszpanię i niektóre kraje Rzeszy) oraz Anglią (w koalicji z Holandią, Austrią, Portugalią, Sabaudią i Prusami). Jakub gromadzi wszelkie wieści pochodzące z teatru działań wojennych i niezwłocznie przekazuje je ojcu opatrując własnymi interpretacjami (niekiedy niezupełnie adekwatnymi), tak jak w poniższym fragmencie: $O$ Traktatach Duńskich z królem Szwedzkim [Karolem XII] i Ksiązęciem Holszteńskim [Fryderykiem IV ks. Holestein-Gottorp] nie wiem czy doszła wiadomość które niedawno konkludowane

34 Emmanuel Thèodose de Bouillon (1643-1715) - duchowny i dyplomata (w korespondencji określany nazwiskiem Boulon). Reprezentował Ludwika XIV w Stolicy Apostolskiej, jednakże doszło pomiędzy nim a królem do konfliktu o podłożu ideologicznym, co skutkowało odwołaniem kardynała z Rzymu i konfiskatą dóbr (W. St. Magdziarz, Ludwik XIV, Wrocław 2004, s. 185, 193).

35 Prawdopodobnie mowa o Marii Kazimierze de la Grange d'Arquien Sobieskiej, wdowie po Janie III Sobieskim i królowej Rzeczypospolitej w 1. 1674-1696. Jakub Dunin mógł nadal tytułować ją monarchinią polską, zważywszy na to, iż jej następczyni Krystyna Eberhardyna Hohenzollernówna (małżonka Augusta II) nie została oficjalnie koronowana. Co więcej, Maria Kazimiera od 1699 r. przebywała w Rzymie, a będąc związana z tamtejszą elitą mogła faktycznie wspierać kardynała de Boullon. Za tezą tą przemawia również fakt, iż popadła w niełaskę u Ludwika XIV, który zabronił jej składania wizyt na dworze (E. Rudzki, Polskie królowe, t. II, Żony królów elekcyjnych, Warszawa 1990, s. 193).

${ }^{36}$ ANKr Oddział I, ATKob 33, k. 25-26, List J. Dunina do Ś. F. Dunina, Paryż 2 IX 1700. 
[zakończone] znacznym profitem króla Duńskiego [Fryderyka IV Oldenburg] co u Nas zapewne [wzmocniło] króla JMCi Naszego [Augusta II Wettyna] imperia [...] $]^{37}$.

Analiza sytuacji politycznej dokonana przez Jakuba Dunina w tym przypadku niezupełnie odpowiada rzeczywistości, ponieważ opisany przez niego traktat w Travendal (19 sierpnia 1700 r.) był skutkiem klęski, jaką poniosła Dania w walce ze Szwecją już w pierwszym etapie wielkiej wojny północnej. Jako kraj przegrany musiała wycofać się z konfliktu, co znacznie osłabiło, a nie jak twierdzi Dunin, wzmocniło Saksonię, która nadal pozostała uwikłana $\mathrm{w}$ wyniszczające walki z silniejszym przeciwnikiem.

Dużo bardziej skrupulatna relacja odnosi się do innych wydarzeń, mianowicie do sytuacji panującej w ościennych Prusach. W korespondencji Jakub znów wspomina o swojej bytności na francuskim dworze, gdzie był podejmowany wraz z ks. Janem Mikołajem Radziwiłłem. Zatem miał sposobność zebrania aktualnych informacji, zważywszy na to, iż książę angażował się wspólnie ze Stolicą Apostolską w protest przeciwko koronacji Fryderyka I Hohenzollerna w której widział zagrożenie dla rodzimych interesów. Dunin wspomina: Tam bawiliśmy się blisko tygodnia różne oddając i odbierając wizyty gdzie będąc Ksiądz Nuncjusz tutejszy dziękowat [...] Ksiązęciu JMci za uczynienie tej protestacji przeciwko koronacji Ksią̇ęcia Brandenburskiego ${ }^{38}$ i powiadat że i Papież [Klemens XI] idac exemplo [przykładem] Ksiażęcia JMci wydat Breve [pismo] przeciw tejże koronacji [oraz] listy do Panów Chrześcijańskich wystat, aby nie uznali go za króla, których obiecat dać copiam [kopie] Ksiażęciu JMci ${ }^{39}$.

Wzmocnienie polityczne Prus wywołało wielkie poruszenie również w Wersalu, jednakże Ludwik XIV był już wówczas zaabsorbowany przygotowaniami do wojny o sukcesję hiszpańską, co doskonale uchwycił Jakub Dunin jako naoczny świadek wydarzeń: [...] wszystkie sa gotowości wojska francuskie, którego jest na trzykroć sto tysięcy jedne do Wtoch drugie do Holandii poszty [...] pewne traktaty Francji z Hiszpania [...] cruentissimum [okrutną] przyniosa belllum [wojnę] Francji i Hiszpanii z Holendrami, Cesarzem, Anglikami. Teraz król Francuski między Elektorów i udzielnych Książat Niemieckich wielkie rozdaje pensje które na trzydzieści sześć milionów tutecznej monety czyniq, a to dlatego aby [neutralność] trzymali $[\ldots]^{40}$.

Przytoczony fragment listu ukazuje trafne spostrzeżenia dotyczące genezy konfliktu, mianowicie wspomniane traktaty to nic innego jak testament władcy hiszpańskiego Karola II, gdzie wyznaczył na swego następcę Filipa d’Anjou - wnuka Króla Słońce. Fakt ten spowodował pojawienie się silnej koalicji antyfrancuskiej, której osią są państwa wymienione przez Dunina. Wojna jeszcze oficjalnie nie została wypowiedziana, lecz armia francuska już w pełni zmobilizowana rozpoczęła działania przeciwko wojskom ce-

\footnotetext{
37 Ibidem, k. 26-27.

3818 stycznia $1701 \mathrm{r}$.

${ }^{39}$ ANKr Oddział I, ATKob 33, k. 29-30, List J. Dunina do Ś. F. Dunina, Paryż 22 V 1701.

40 Ibidem, k. 30-31.
} 
sarskim w północnych Włoszech ${ }^{41}$. Jakub wspomina jeszcze o subsydiach, jakie słał Ludwik XIV do państw Rzeszy, lecz miały one zapewnić nie neutralność, tylko pomoc dla Francji w postaci kontyngentów wojskowych, które w istocie zapewniła Bawaria oraz Kolonia. Kolejny list Dunina do ojca również zawiera wzmianki dotyczące wojny, bowiem pisze on: $Z$ gazet mało co [wiadomo] tylko że wojska króla JMci Francuskiego kilkadziesiąt tysięcy poszło na sukurs Mediolanu. Cesarski i Brandenburski Postowie odjeżdżaja ode dworu, ponieważ Książe Brandenburski daje wojsk swoich Cesarzowi ${ }^{42}$. $\mathrm{W}$ tym przypadku są to również informacje zgodne z rzeczywistością, ponieważ potwierdzają kampanię włoską oraz przynależność Prus do przymierza przeciwko Francji. W zaistniałej sytuacji utrzymywanie ambasadora habsburskiego i pruskiego w Wersalu faktycznie traciło zasadność, co słusznie zauważa autor listu.

Pobyt Jakuba Dunina i książąt Radziwiłłów w Paryżu trwał prawie półtorej roku (od marca 1700 r. do sierpnia 1701 r.). Przed udaniem się w dalszą podróż złożyli oni wiele wizyt pożegnalnych, m.in. na dworze, gdzie dat im król prywatny $w$ gabinecie swoim audiencję do którego [...] mówit Ksiązę JM Krajczy WXL na co mu sam król odpowiedziat wdzięcznym się bądź afektu Xiażąt Ich Mościów i pamiętnym deklarując, znając dawno [wielkość] Domu Ich przy oddzielnej godności i talentach Książą Ich Mościów $[\ldots]^{43}$. Następnie udali się w odwiedziny Delfina francuskiego - Ludwika Burbona oraz wielu innych osobistości związanych z rodziną królewską. Jakub wspomina, iż wszędzie byli podejmowani $\mathrm{z}$ wielkimi honorami, ponieważ [...] kilka dni przed pożegnaniem grały wody i fontanny ogrodu Wersalskiego dla Ksiązat Ich Mościów gdzie [w obecności] tak Ich Mościów Panów Polaków jako i innych wielu cudzoziemców wożono nas po ogrodzie w ruletach królewskich, potem batami bogatymi jeździliśmy do innych pataców po kanale ${ }^{44}$.

Po tygodniowej bytności w Wersalu, peregrynanci pojechali do Saint-Germain, aby pożegnać zdetronizowanego króla angielskiego Jakuba II Stuarta przebywającego na wygnaniu we Francji ${ }^{45}$. Pomimo złego stanu zdrowia były monarcha przyjął ich z wielką życzliwością. Dunin ubolewał nad losem wygnańca i jego małżonki, którzy za wiare cierpia od zięcia swego [Wilhelm III Orański] z tronu zrzuceni i z państwa wygnani będac $[\ldots]^{46}$. Sytuacja ta rzeczywiście musiała wydać się kontrowersyjna dla Polaków, bowiem w Rzeczypospolitej nie było jeszcze wówczas precedensu, aby władców zrzucano $\mathrm{z}$ tronu.

${ }^{41}$ T. Miłkowski, P. Machcewicz, Historia Hiszpanii, Wrocław 2002, s. 201.

${ }^{42}$ ANKr Oddział I, ATKob 33, k. 33-34, List J. Dunina do Ś. F. Dunina, Paryż 14 VI 1701.

${ }^{43}$ ANKr Oddział I, ATKob 33, k. 37, List J. Dunina do Ś. F. Dunina, Paryż 29 VIII 1701.

${ }^{44}$ Ibidem, k. 38.

${ }^{45}$ Ludwik XIV udzielił schronienia Stuartowi i jego rodzinie, oddając im do użytku pałac w Saint-Germain (M. Niemojowska, Ostatni Stuartowie, Warszawa 1992, s. 14).

${ }^{46}$ ANKr Oddział I, ATKob 33, k. 38, List J. Dunina do Ś. F. Dunina, Paryż 29 VIII 1701. 
W trakcie pobytu we Francji miało miejsce doniosłe wydarzenie dla Jakuba Dunina, mianowicie 22 sierpnia 1701 r. został kawalerem Orderu św. Łazarza i Najświętszej Marii Panny z Góry Karmel ${ }^{47}$. Wyróżnienie to było inicjatywą ks. Jana Mikołaja, który pokrył koszty związane z nominacją oraz zakupił sam order ${ }^{48}$. Wedle szacunku Dunina miała to być suma opiewająca na ok. 600 talarów. Fakt ten nie jest zaskakujący, ponieważ należy pamiętać, że Jakub Dunin nie piastował jeszcze wtedy żadnego urzędu, natomiast Radziwiłł zadbał o to, by jako członek jego świty korzystniej prezentował się na oficjalnych audiencjach w charakterze kawalera wspomnianego orderu. Aby zostać tzw. „kawalerem z prawa” Jakub musiał wykazać swoje szlachectwo na kilka pokoleń wstecz zarówno po mieczu, jak i po kądzieli, dlatego pisał do ojca o przysłanie stosownych dokumentów $^{49}$. Tytuł miał znaczenie symboliczne, jednak był przydatny w początkowej fazie kariery Dunina, bowiem świadczył o odbytej zagranicznej peregrynacji i kontaktach z wpływowymi środowiskami ówczesnej Europy.

Kolejnym celem podróży miała być Flandria, a później Holandia i Anglia ${ }^{50}$. Niestety, nie zachowała się żadna korespondencja pochodząca z tych krajów, natomiast następny z listów datowany jest już z Wenecji. Jakub opisuje w nim wjazd publiczny Posła Francuskiego [...] w niedziele [...] odprawować się będzie i tak tu znowu maty karnawat mieć będziemy ${ }^{51}$. Jednak eskapada powoli zmierza ku końcowi, bowiem w relacji z Wiednia Dunin donosi, iż podróżnicy kierują się ku granicom Rzeczypospolitej, gdzie spodziewają się dotrzeć w latem 1703 r. ${ }^{52}$

Kilkuletni pobyt za granicą był niewątpliwie ważną częścią edukacji każdego szlachcica. Przykład peregrynacji Jakuba Dunina ukazuje jak ogromne korzyści płynęły z bezpośredniego zetknięcia się z innym niż ojczysty kręgiem kulturowym, jednakże nie jest zjawiskiem odosobnionym. Analogiczne wojaże z wszystkimi ich aspektami, odbywało wielu przedstawicieli młodego pokolenia szlachty i magnaterii, na co wskazuje chociażby opracowywana korespondencja, gdzie przewijają się nazwiska Tarłów, Sanguszków czy Dłużeckich, których Jakub poznał właśnie w czasie swej bytności w Paryżu ${ }^{53}$. Nawiązane wówczas kontakty z pewnością przysłużyły się późniejszemu skoligaceniu rodziny Duninów z Sanguszkami ${ }^{54}$.

47 Ibidem, k. 39.

48 Order św. Łazarza i NMP z Góry Karmel był nadawany przez jeden z najbardziej elitarnych zakonów działających na terenie Francji, czyli Połączonego Zakonu Królewskiego, Rycerskiego i Szpitalnego NMP z Góry Karmel i św. Łazarza z Jerozolimy (unifikacja zakonów nastąpiła w 1607 r.).

49 ANKr Oddział I, ATKob 33, k. 39, List J. Dunina do Ś. F. Dunina, Paryż 29 VIII 1701.

${ }^{50}$ Ibidem.

${ }^{51}$ ANKr Oddział I, ATKob 33, k. 41, List J. Dunina do Ś. F. Dunina, Wenecja 28 IV 1703.

${ }^{52}$ ANKr Oddział I, ATKob 33, k. 45, List J. Dunina do Ś. F. Dunina, Wiedeń 27 V 1703.

${ }_{53}$ ANKr Oddział I, ATKob 33, k. 14, List J. Dunina do Ś. F. Dunina, Paryż 19 III 1700. oraz ANKr Oddział I, ATKob 33, k. 22, List J. Dunina do Ś. F. Dunina, Paryż 6 VIII 1700.

${ }^{54}$ Córka Jakuba Dunina - Barbara (1718-1791) w 1735 r. wyszła za mąż za Pawła Karola Sanguszkę (1680-1750). 
Eskapada Jakuba Dunina i książąt Radziwiłłów jawi się jako typowa dla ówczesnych, staropolskich standardów edukacyjnych. Nie bez powodu wybrano Paryż na główny ośrodek w którym pobierano naukę, bliskość bowiem dworu królewskiego odegrała istotną rolę w kształtowaniu postaw towarzyskich i obyczajowych, co odpowiadało aspiracjom peregrynantów. Wyprawa umożliwiła ponadto doskonalenie umiejętności praktycznych związanych, np. ze sztuką wojskową czy z władaniem językami obcymi, co więcej zainicjowała analizę ówczesnej sytuacji politycznej. Dzięki zawartym znajomościom oraz wykształceniu i doświadczeniom zdobytym podczas wojaży Jakub Dunin mógł po powrocie do kraju bez przeszkód rozwinąć karierę w służbie publicznej.

\section{Bibliografia}

Źródła archiwalne

Archiwum Narodowe w Krakowie (Oddział I), zespół akt: Archiwum Tomkowiczów z Kobiernic (ATKob) sygn. 33

\section{Opracowania}

Chachaj M., Orszak magnata odbywającego podróż edukacyjna (wiek XVI-XVIII), w: Patron i dwór. Magnateria Rzeczypospolitej w XVI-XVIII wieku, red. E. Dubas-Urwanowicz, J. Urwanowicz, Warszawa 2006.

Dzięgielewski R., Przygotowanie młodzieży do podróży akademickiej w XVI-XVIII wieku na przykładzie traktatów apodemicznych, w szczególności „Brewiarza apodemicznego” gdańszczanina Samuela Zwickera, Gdańsk 2015.

Epistolografia $w$ dawnej Rzeczypospolitej, $t$. VI (stulecia XVI-XIX). Nowa perspektywa historyczna i jezzykowa, red. P. Borek, M. Olma, Kraków 2015.

Górzyński S., Grala J., Piwkowski W., Urbaniak V., Zielińska T., Radziwiłłowie herbu Trąby, Warszawa 1996.

Kamecka M., „Do cudzych krajów”. Edukacyjne podróże szlachty polskiej do Francji w epoce saskiej, Białystok 2012.

Kicińska U., Pedagogiczny aspekt podróżowania w dawnej Polsce, w: Polski Grand Tour w XVIII i początkach XIX wieku, red. A. Roćko, Warszawa 2014.

Kobiece kręgi korespondencyjne w XVII-XIX wieku, red. B. Popiołek, U. Kicińska, A. Słaby, Warszawa 2016.

Konopczyński W., Jakub Dunin ze Skrzynna, w: PSB, t. V, Kraków 1939-1946.

Kupisz D., Rody szlacheckie ziemi radomskiej, Radom 2009.

Magdziarz W. St., Ludwik XIV, Wrocław 2004.

Maliszewski K., Komunikacja społeczna w kulturze staropolskiej. Studia z dziejów ksztaltowania się form i treści społecznego przekazu w Rzeczypospolitej szlacheckiej, Toruń 2001.

Mączak A., Peregrynacje. Wojaże. Turystyka, Warszawa 1984.

Miłkowski T., Machcewicz P., Historia Hiszpanii, Wrocław 2002. 
Niemojowska M., Ostatni Stuartowie, Warszawa 1992.

Penkała A., „Nowiny śle pewne i dobre”. Szlacheckie podróże w świetle wybranej matżeńskiej korespondencji XVII i XVIII wieku, w: Via viatores quaerit. Mobilność spoteczna $w$ dziejach krajów Grupy Wyszehradzkiej, red. A. Teterycz-Puzio, L. Kościelak, E. Łączyńska, Słupsk 2016.

Popiołek B., Na marginesie ważnych spraw. Listy kobiet epoki saskiej, w: Rola i miejsce kobiet w edukacji i kulturze polskiej, t. 1, red. W. Jamrożek, D. Żołądź-Strzelczyk, Poznań 1998.

Popiołek B., Peregrynacje edukacyjne i poznawcze w źródłach czasów saskich, w: Polski Grand Tour w XVIII i początkach XIX wieku, red. A. Roćko, Warszawa 2014.

Przestrogi i nauki dla dzieci: instrukcje rodzicielskie (XVIII w.), red. M. E. Kowalczyk, D. Żołądź-Strzelczyk, Wrocław 2017.

Puchowski K., Europejski rodowód kolegiów szlacheckich w Rzeczypospolitej. Rekonesans, w: Staropolski ogląd świata - problem inności, red. F. Wolański, Toruń 2007.

Rok B., Opis podróży Wacława Sierakowskiego (1741-1806) po Europie w latach 1763-1769, w: Z badań nad Rzeczypospolita w czasach nowożytnych, red. K. Matwijowski, Wrocław 2001.

Rudzki E., Polskie królowe, t. II, Żony królów elekcyjnych, Warszawa 1990.

Źródta do dziejów staropolskich podróży edukacyjnych, red. D. Żołądź-Strzelczyk, M. E. Kowalczyk, Wrocław 2017.

Żołądź D., Ideały edukacyjne doby staropolskiej. Stanowe modele i potrzeby edukacyjne szesnastego i siedemnastego wieku, Warszawa-Poznań 1990.

Żołądź-Strzelczyk D., Podróże edukacyjne w staropolskiej myśli pedagogicznej, „Chowanna” t. 2, 1998.

Żołądź-Strzelczyk D., „,Refleksje synowi wyjeżdzającemu do Widnia” - Feliksa Czackiego wskazówki dla syna, w: Staropolskie podróżowanie, red. B. Rok, F. Wolański, Kraków 2016.

Żołądź-Strzelczyk D., Wychowanie dziecka w świetle staropolskiej teorii pedagogicznej, w: Od narodzin do wieku dojrzałego: dzieci i młodzież w Polsce. Czesść 1, Od średniowiecza do wieku XVIII, red. M. Dąbrowska, A. Klonder, Warszawa 2002. 
